\title{
Sugar, Salt and Fat Consumption of Population in Batur Kidul Village Getasan Subdistrict Semarang Regency
}

\section{Gambaran Konsumsi Gula, Garam dan Lemak Penduduk Dusun Batur Kidul Kecamatan Getasan Kabupaten Semarang}

\author{
R.L.N.K. Retno Triandhini ${ }^{{ }^{*},}$, Monika Rahardjo ${ }^{2}$, Magdalena Putranti ${ }^{1}$
}

\begin{abstract}
The prevalence of non-contagious diseases such as diabetes mellitus, hypertension and obesity are increasing from year to year. Unhealthy diet such as excessive consumption of sugar, salt and fat is one of the factors causing these diseases. The result of data analysis shown that $21.5 \%$ of respondents had consumed sugar exceeding the recommendation of Permenkes no 30 year 2013 (>50 gram/day), 73.7\% of respondents consume salt exceeding the recommendation of Permenkes no 30 year 2013 (5 gram/hari), and as many as $7 \%$ of respondents consume fat exceeds the recommendation Permenkes no 30 year 2013 (> 67\% gram /day). The highest consumption of salt and fat occurs in the age group of 56 - 65 years, while the highest sugar consumption occurs in the age group 40 - 45 years. Based on sex, women tends to consume sugar, salt and fat higher than men. Consumption of salt and sugar of respondents is high. This needs special attention because excessive salt and sugar consumption can cause non-contagious diseases such as hypertension and Diabetes Mellitus type 2, whose prevalence in Indonesia is increasing.
\end{abstract}

Keywords: consumption, fat, salt, sugar

Intisari

Penyakit tidak menular seperti diabetes mellitus, hipertensi dan obesitas prevalensinya semakin meningkat dari tahun ke tahun. Pola makan yang tidak sehat yaitu konsumsi garam, gula dan lemak yang berlebihan merupakan salah satu faktor penyebab penyakit ini. Hasil analisis data penelitian menunjukkan sebanyak $21.5 \%$ responden mengkonsumsi gula melebihi rekomendasi Permenkes no 30 tahun 2013 (>50 gram/hari), sebanyak 73,7\% responden mengkonsumsi garam melebihi rekomendasi Permenkes no 30 tahun 2013 (5 gram/hari), dan sebanyak 7\% responden mengkonsumsi lemak melebihi rekomendari Permenkes no 30 tahun 2013 (>67\% gram/hari). Konsumsi Garam dan lemak tertinggi terjadi pada kelompok usia $56-65$ tahun, sedangkan konsumsi gula tertinggi terjadi pada kelompok usia $40-45$ tahun. Berdasarkan jenis kelamin, perempuan cenderung mengkonsumsi gula, garam dan lemak yang lebih tinggi dibandingkan laki-laki. Konsumsi garam dan gula responden yang

Afiliasi Penulis

1 | Prodi Gizi, Fakultas Kedokteran dan Ilmu Kesehatan, Universitas Kristen Satya Wacana.

2 | Prodi Teknologi Pangan, Fakultas Kedokteran dan IImu Kesehatan, Universitas Kristen Satya Wacana.

Korespondensi kepada

R.L.N.K. Retno Triandhini

retno.triandhini@staff.uksw.ac.id tergolong tinggi ini perlu mendapat perhatian khusus karena konsumsi garam dan gula yang berlebihan dapat menyebabkan berbagai penyakit tidak menular seperti hipertensi dan Diabetes Mellitus tipe 2 yang prevalensinya di Indonesia semakin meningkat.

Kata Kunci : konsumsi, garam, gula, lemak 


\section{Pendahuluan}

Negara Indonesia, saat ini masih menghadapi beban ganda dalam masalah kesehatan. Penyakit infeksi atau menular seperti HIV/AIDS, tuberkulosis, pneumonia, kusta, dan diare masih menjadi tantangan yang harus dihadapi, dipihak lain masalah penyakit tidak menular (PTM) seperti diabetes mellitus, hipertensi dan obesitas prevalensinya semakin meningkat dari tahun ke tahun. Berdasarkan data Riset Kesehatan Dasar (Riskesdas) tahun 2007 dan 2013 terjadi kecenderungan peningkatan prevalensi penyakit diabetes mellitus yaitu 1,1 persen di tahun 2007 meningkat menjadi 2,1 persen pada tahun 2013, prevalensi penyakit hipertensi yaitu 7,6 persen di tahun 2007 meningkat menjadi 9,5 persen pada tahun 2013. Terjadi juga kecenderungan peningkatan prevalensi obesitas penduduk laki laki dewasa (>18 tahun) yaitu 13,9 persen di tahun 2007 meningkat menjadi 19,7 persen pada tahun 2013 dan peningkatan prevalensi obesitas penduduk perempuan dewasa (>18 tahun) yaitu 18,1 persen di tahun 2007 meningkat menjadi 32,9 persen pada tahun 2013 (Kemenkes RI, 2007; Kemenkes RI, 2013).

Penyakit tidak menular khususnya yang tergolong dalam penyakit kardiometabolik disebabkan oleh beberapa faktor antara lain usia, kurangnya aktifitas fisik dan pola makan yang buruk. Usia menjadi faktor yang berhubungan dengan penyakit tidak menular, karena seseorang yang sudah lanjut usia mengalami penurunan fungsi fisiologis pada tubuh (Ekpenyong et al., 2012; Feng et al., 2014). Pola makan berisiko yang mengakibatkan penyakit tidak menular meliputi pola konsumsi makanan atau minuman manis, makanan asin, makanan berlemak yang melebihi batas rekomendasi. Pola konsumsi makanan seperti ini berdampak pada meningkatnya kasus penyakit kardiometabolik seperti penyakit hipertensi, obesitas, dan penyakit diabetes mellitus (Kemenkes RI, 2013). Berbagai penelitian menunjukkan bahwa konsumsi gula, garam, dan lemak berhubungan erat dengan terjadinya kasus penyakit kardiometabolik. Penelitian yang dilakukan oleh Murti (2016) menunjukkan ada hubungan antara kebiasaan konsumsi gula dengan kejadian diabetes mellitus di wilayah kerja Puskesmas Leyengan Ungaran Timur Kabupaten Semarang, dengan $p$-value sebesar 0,013 ( $\alpha=0,05)$. Begitu juga penelitian yang dilakukan oleh $\mathrm{He}$ et al. (2012) menunjukkan adanya hubungan yang signifikan antara penurunan kejadian penyakit kardiovaskular dalam pengurangan asupan garam, diperoleh nilai $(p<0,05)$ Penelitian lain di Puskesmas Pattingalloang Kota Makassar menyatakan bahwa terdapat hubungan antara asupan lemak dengan kejadian hipertensi dengan nilai ( $p=0,000$ ) (Rawasiah et al., 2012)

Hasil survei konsumsi makanan individu di Indonesia tahun 2014, menunjukkan bahwa penduduk Indonesia rata-rata mengkonsumsi gula sebesar 14,2 gram, garam 3,6 gram, dan minyak 20,6 gram (Badan Penelitian dan Pengembangan Kesehatan, 2014). Pada provinsi Jawa Tengah sendiri, hasil survei konsumsi makanan individu tahun 2014 menunjukkan bahwa konsumsi lemak sebesar 63.6 gram per orang per hari, konsumsi gula sebesar 22,9 gram per orang per hari, konsumsi garam sebesar 4 gram per orang per hari (Santoso et al, 2014) Hal ini menunjukkan bahwa konsumsi gula, garam dan lemak masyarakat Indonesia telah mendekati batas rekomendasi dari Permenkes No. 30 tahun 2013 yang mengatakan bahwa batas konsumsi gula, garam, dan lemak yang disarankan oleh Kementrian Kesehatan RI per orang per hari yaitu 50 gram gula (4 sendok makan), 2000 miligram natrium/sodium yang setara 5 gram garam (1 sendok teh), dan untuk lemak hanya 67 gram (5 sendok makan) (Permenkes, 2014).

Menurut data Profil Kesehatan Kabupaten Semarang tahun 2014, yang termasuk dalam 3 besar penyakit tidak menular di Kabupaten Semarang adalah hipertensi esensial (25.541 kasus), hipertensi lain (9.330 kasus), diabetes mellitus non insulin (8.843 kasus). Dalam 2 tahun terakhir, penyakit hipertensi masih menjadi urutan pertama kasus penyakit tidak menular terbesar di Kabupaten Semarang (Dinkes Semarang, 2015). Kecamatan Getasan merupakan salah satu daerah yang terletak di Kabupaten Semarang, menurut data Profil Kesehatan Puskesmas Getasan 2014, Desa Batur Kecamatan Getasan memiliki masalah kasus penyakit tidak menular tertinggi, seperti 
diabetes mellitus (36 kasus), hipertensi Essensial (54 kasus), dan hipertensi lain (65 kasus). Sampai saat ini, data tentang penyakit, khususnya penyakit tidak menular seperti hipertensi dan diabetes mellitus dapat ditemukan pada Profil Kesehatan tingkat Kecamatan atau Desa namun data tentang survei diet total atau pola konsumsi tidak pernah dilakukan secara detail di tingkat ini. Padahal pola konsumsi makanan sangat erat kaitannya dengan timbulnya penyakit khususnya penyakit tidak menular.

Berdasarkan uraian di atas, penelitian ini bertujuan untuk mengetahui konsumsi gula, garam, dan lemak pada penduduk Dusun Batur Kidul Kecamatan Getasan Kabupaten Semarang yang melebihi rekomendasi Permenkes no 30 tahun 2013.

\section{Metode}

Penelitian analisis konsumsi gula, garam, dan lemak dilakukan di Dusun Batur Kidul Desa Batur Kecamatan Getasan yang menurut data Profil Kesehatan Puskesmas Getasan 2014 memiliki masalah kasus penyakit tidak menular tertinggi. Dusun Batur Kidul dijadikan lokasi penelitian dengan pertimbangan memiliki lokasi yang mudah diakses dan memiliki jumlah penduduk terbanyak dibandingkan dusun yang lainnya. Penelitian ini dilaksanakan selama 3 bulan yaitu pada bulan Januari - Maret 2017. Jenis penelitian ini merupakan penelitian deskriptif dengan pendekatan cross sectional. Populasi dalam penelitian ini adalah seluruh penduduk Dusun Batur Kidul Kecamatan Getasan Kabupaten Semarang yang berusia diatas 40 tahun. Teknik pengambilan sampel dilakukan secara Simple random sampling. Jumlah sampel sebanyak 186 orang ditentukan berdasarkan tabel Isaac dan Michael dengan tingkat kesalahan $5 \%$.

Pengumpulan data pola konsumsi pangan untuk konsumsi gula, garam dan lemak diperoleh melalui metode recall $1 \times 24$ jam selama 3 hari yang dilakukan pada 2 kali hari kerja (working day) dan 1 kali pada hari libur (weekend day). Data identitas responden diperoleh dari kuisioner dan hasil wawancara, data IMT diperoleh melalui pengukuran berat badan dan tinggi badan. Data karakteristik sampel diperoleh dari data kependudukan yang diambil dari kelurahan. Analisis data gula, garam, dan lemak dikonversikan ke dalam zat gizi dengan menggunakan Daftar Komposisi Bahan Makanan (DKBM), kemudian angka zat gizi dilihat pola sebarannya dengan program Microsoft Excel kemudian dibandingkan dengan rekomendasi dari Permenkes No. 30 Tahun 2013.

\section{Hasil \& Pembahasan}

\section{Karakteristik Responden}

Distribusi karakteristik responden yang meliputi umur, jenis kelamin, pekerjaan, dan latar belakang
Tabel 1 | Distribusi responden menurut karakteristik usia, jenis kelamin, pekerjaan dan latar belakang pendidikan

$\begin{array}{lll}\text { Karakteristik } & \text { n } & \%\end{array}$

\begin{tabular}{|c|c|c|c|}
\hline \multicolumn{4}{|l|}{ Kelompok Umur } \\
\hline & $40-45$ tahun (Dewasa Akhir) & 46 & 24,7 \\
\hline & 46 - 55 tahun (Lansia Awal) & 62 & 33,3 \\
\hline & $56-65$ tahun (Lansia Akhir) & 45 & 24,2 \\
\hline & $>65$ tahun (Manula Atas) & 33 & 17,8 \\
\hline \multicolumn{4}{|l|}{ Jenis Kelamin } \\
\hline & Laki - Laki & 81 & 43,5 \\
\hline & Perempuan & 105 & 56,5 \\
\hline \multicolumn{4}{|l|}{ Latar Belakang Pendidikan } \\
\hline & Tidak Sekolah & 32 & 17.2 \\
\hline & SD & 146 & 78.5 \\
\hline & SMP & 7 & 3.8 \\
\hline & S1 & 1 & 0.5 \\
\hline \multicolumn{4}{|l|}{ Pekerjaan } \\
\hline & Tani & 184 & 99 \\
\hline & Perangkat Desa & 1 & 0.5 \\
\hline & Guru & 1 & 0.5 \\
\hline
\end{tabular}


pendidikan dapat dilihat pada tabel 1. Responden dikelompokan menjadi 4 kelompok umur yaitu kelompok umur dewasa akhir (40 - 45 tahun), lansia awal (46 - 55 tahun), lansia akhir (56- 65 tahun) dan manula atas (> 65 tahun) (Depkes RI, 2009). Dari keempat kelompok usia tersebut, responden paling banyak adalah kelompok umur $46-55$ tahun, yaitu 62 orang $(33,3 \%)$ dan yang paling sedikit kelompok umur $>65$ tahun sebanyak 33 orang $(17,8 \%)$. Jumlah responden perempuan lebih banyak yaitu 105 orang (56,5\%) dibandingkan laki-laki yaitu 81 orang (43,5\%). Dari 186 responden sebanyak 32 orang tidak mengeyam pendidikan di bangku sekolah, 7 orang memiliki latar belakang pendidikan di tingkat Sekolah Menengah Pertama, 1 orang memiliki latar belakang pendidikan sebagai Sarjana, dan sebagian besar responden memiliki latar belakang pendidikan Sekolah Dasar yaitu sebanyak 146 orang. Hampir seluruh responden bekerja sebagai petani (184 orang) dan hanya 2 orang yang bukan petani, 1 orang bekerja sebagai perangkat desa dan 1 orang merupakan guru.

Pada tabel 2 disajikan data IMT responden berdasarkan kelompok umur dan jenis kelamin. Dari data IMT yang dilihat secara keseluruhan, 155 orang responden (83.3\%) memiliki IMT normal, 18 orang responden $(9.7 \%)$ memiliki IMT kategori gemuk, dan hanya 13 orang responden (7\%) memiliki IMT kategori kurus. Pada kelompok umur 40 - 45 tahun memiliki persentase IMT kategori gemuk terbanyak yaitu $13 \%$, persentase IMT kategori normal terbanyak pada kelompok umur 45 - 55 tahun yaitu 88,7\%, dan persentase IMT kategori kurus terbanyak pada kelompok umur $>65$ tahun yaitu $27,3 \%$. Laki - laki memiliki kategori IMT normal $(86,4 \%)$ dan gemuk $(9,9 \%)$ lebih tinggi dibandingkan dengan perempuan yaitu IMT normal (81\%) dan gemuk (9,5\%). Perempuan memiliki kategori IMT kurus $(9,5 \%)$ lebih tinggi dibandingkan dengan laki - laki $(3,7 \%)$.

Indeks massa tubuh (IMT) merupakan salah satu indikator yang digunakan pada orang dewasa untuk menentukan seseorang memiliki berat badan kurang, normal, dan gemuk (obesitas). Obesitas terjadi akibat penumpukan lemak berlebih pada tubuh yang dapat mengakibatkan gangguan kesehatan seperti penyakit jantung, diabetes mellitus, dan kolestrol tinggi (Nugraha, 2014). Dari analisis data diatas, sebanyak $7 \%$ responden memiliki kategori IMT kurus terbanyak yang terdapat pada kelompok umur manula atas (>65 tahun). Hal ini karena responden pada kelompok umur manula atas (>65 tahun) terjadi penurunan nafsu makan. Selain itu sebanyak $9.7 \%$ responden memiliki kategori IMT gemuk terbanyak yang terdapat pada kelompok umur $40-45$ tahun. Tingginya kategori IMT gemuk pada kelompok umur ini terjadi karena penerapan gaya hidup tidak sehat, seperti mengkonsumsi makanan/minuman manis melebihi kebutuhan tubuh yang menjadi penyebab terjadinya obesitas. Tingginya persentase kategori IMT gemuk pada kelompok umur 40-45 tahun perlu mendapatkan perhatian khusus, sebab jika tidak obesitas dapat meningkatkan resiko terkena penyakit hipertensi 2,5 kali, penyakit jantung 32 persen, diabetes mellitus 5,45 kali (Bogers et al., 2007; Prasetyani dan Solikin, 2017).

\begin{tabular}{|c|c|c|c|c|c|c|c|}
\hline & Karakteristik & Normal & $\%$ & Gemuk & $\%$ & Kurus & $\%$ \\
\hline \multicolumn{8}{|l|}{ Kelompok Umur } \\
\hline & $40-45$ thn & 40 & 87 & 6 & 13 & 0 & 0 \\
\hline & $46-55$ thn & 55 & 88.7 & 7 & 11.3 & 0 & 0 \\
\hline & $56-65$ thn & 39 & 86.7 & 2 & 4.4 & 4 & 8.9 \\
\hline & $>65$ thn & 23 & 69.7 & 1 & 3 & 9 & 27.3 \\
\hline \multicolumn{8}{|l|}{ Jenis Kelamin } \\
\hline & Laki - laki & 70 & 86.4 & 8 & 9.9 & 3 & 3.7 \\
\hline & Perempuan & 85 & 81 & 10 & 9.5 & 10 & 9.5 \\
\hline Total & & 155 & 83.3 & 18 & 9.7 & 13 & 7 \\
\hline
\end{tabular}

Pengkategorian status gizi berdasarkan Depkes RI 2003 


\section{Konsumsi Gula}

Gula yang dimaksudkan di sini adalah gula yang ditambahkan dalam bahan makan seperti gula pasir, gula jawa, dan gula batu. Pada tabel 3 disajikan rata - rata konsumsi gula menurut kelompok umur dan jenis kelamin. Dapat dilihat, rata - rata konsumsi gula adalah 43 gram per orang per hari, laki - laki mengkonsumsi gula lebih banyak yaitu 43,8 gram per orang per hari dibandingkan dengan perempuan yaitu 42.4 gram per orang per hari. Konsumsi gula tertinggi terlihat pada kelompok umur $40-45$ tahun sebesar 49.5 gram per orang per hari dan terendah pada kelompok umur $56-65$ tahun yaitu 38.5 gram per orang per hari. Rata-rata konsumsi gula ini masih dalam batas yang direkomendasikan oleh Permenkes No. 30 tahun 2013 yakni $<50$ gr per harinya. Meskipun demikian, rata-rata konsumsi gula ini lebih tinggi jika dibandingkan data rata-rata konsumsi gula penduduk Jawa Tengah yaitu sebesar 22,8 g/org/hari untuk kelompok usia $19-55$ tahun dan
24,4 g/org/hari untuk kelompok usia > 55 tahun (Santoso et al., 2014).

Penyebaran data asupan gula berdasarkan kelompok umur pada responden laki-laki dan perempuan disajikan dalam diagram box-plot (Gambar 1). Semakin panjang bidang persegi maka data semakin menyebar, artinya variasi data lebih beragam. Hal ini tampak pada gambar 1a (responden laki-laki), dimana data konsumsi gula pada kelompok umur 56-65 tahun paling bervariasi, sedangkan pada kelompok umur $>65$ tahun penyebaran data paling terpusat. Sebaliknya pada gambar $1 b$ (responden perempuan), pada kelompok umur 56-65 variasi data konsumsi gula paling kecil dibanding tiga kelompok usia yang lain. Dilihat dari kecenderungan data maka pada gambar 1a, data kelompok umur 40-45 tahun dan kelompok umur 46-65 tahun tidak simetris, tidak mengikuti distribusi normal. Data kelompok usia 56-65 tahun dan $>65$ tahun mengikuti distribusi normal.

Tabel 3 | Rerata asupan gula (g/org/hr) menurut karakteristik kelompok umur dan jenis kelamin.

\begin{tabular}{|c|c|c|c|c|c|c|}
\hline \multirow{2}{*}{$\begin{array}{l}\text { Kelompok } \\
\text { Umur }\end{array}$} & \multicolumn{2}{|c|}{ Laki - Laki } & \multicolumn{2}{|c|}{ Perempuan } & \multicolumn{2}{|c|}{ Total } \\
\hline & Rerata \pm SD & Min-Max & Rerata \pm SD & Min-Max & Rerata \pm SD & Min-Max \\
\hline $40-45$ thn & $49.5 \pm 11.3$ & $17.3-72.1$ & $48.1 \pm 19.2$ & $3.5-80.6$ & $48.9 \pm 15.4$ & $3.5-80.6$ \\
\hline $46-55$ thn & $41.6 \pm 18.1$ & $5.7-61.5$ & $45.1 \pm 14.8$ & $12.5-65.2$ & $43.8 \pm 16.2$ & $5.7-65.2$ \\
\hline $56-65$ thn & $38.5 \pm 21.7$ & $1.5-82.3$ & $35.9 \pm 17.9$ & $9-91.3$ & $37.1 \pm 19.6$ & $1.5-91.3$ \\
\hline$>65$ thn & $45.4 \pm 12.9$ & $9.5-62.5$ & $41.0 \pm 15.5$ & $5.5-60$ & $42.6 \pm 14.5$ & $5.5-62.5$ \\
\hline Total & $43.8 \pm 17.1$ & $1.5-82.3$ & $42.4 \pm 17.3$ & $3.5-91.3$ & $43 \pm 17.2$ & $1.5-91.3$ \\
\hline
\end{tabular}

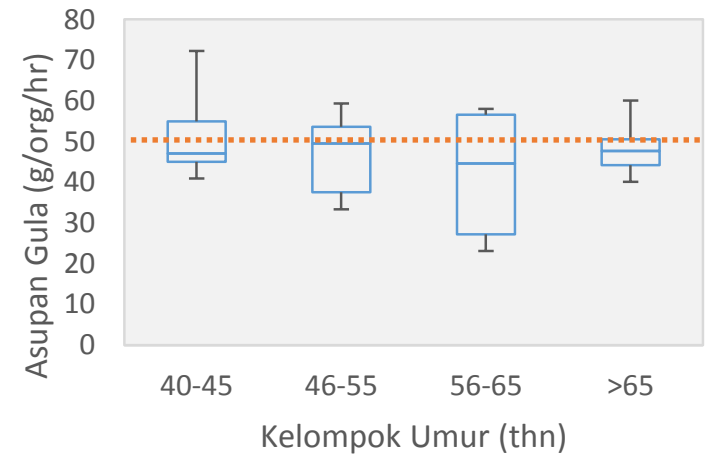

a

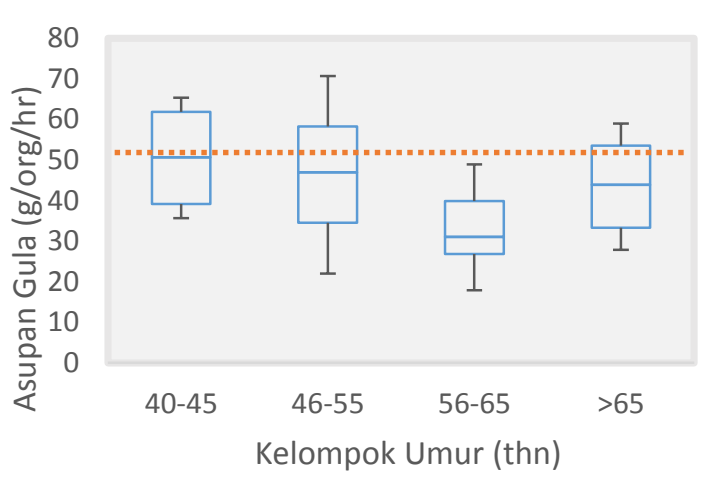

b

Gambar 1 | Konsumsi gula berdasarkan kelompok umur

a. Laki-laki. b. Perempuan. (garis merah putus-putus = batas atas rekomendasi Permenkes No. 30 Tahun 2013) 
Pola konsumsi makan yang tidak sehat yaitu tinggi gula, garam dan lemak merupakan salah satu faktor penyebab terjadinya penyakit tidak menular seperti penyakit jantung, pembuluh darah dan diabetes mellitus yang sudah terjadi pada seluruh kalangan penduduk didaerah perkotaan maupun pedesaan baik di kalangan sosial ekonomi menengah keatas maupun sosial ekonomi menengah kebawah (Kemenkes, 2011).

Gula merupakan karbohidrat sederhana yang digunakan untuk meningkatkan cita rasa, selain itu gula berfungsi sebagai sumber energi bagi tubuh. Jenis gula yang dikonsumsi penduduk Dusun Batur Kidul sebagai gula yang ditambahkan pada makanan dan minuman adalah gula pasir, gula batu, dan gula merah. Meskipun gula dapat menjadi salah satu sumber energi bagi tubuh, namun jika mengkonsumsi gula secara berlebih maka dapat meningkatkan resiko timbulnya penyakit diabetes mellitus dan obesitas (Murti, 2016)

Dari data analisis, secara umum rata-rata konsumsi gula tidak melebihi batas rekomendasi pemerintah tetapi lebih tinggi dari rata-rata konsumsi penduduk Indonesia. Jika dilihat lebih rinci, dimana dibedakan antara responden yang mengkonsumsi diatas rekomendasi dan yang tidak maka diketahui bahwa sebanyak $21,5 \%$ responden mengkonsumsi gula melebihi batas rekomendasi dan yang terbanyak pada kelompok usia produktif yaitu 40 - 45 tahun. Data ini menunjukkan bahwa sebagian responden memiliki mengkonsumsi gula yang tinggi.

Berdasarkan wawancara dan data recall 24 jam yang dilakukan kepada responden, gula yang paling banyak dikonsumsi adalah gula pasir. Gula selain ditambahkan pada makanan juga ditambahkan pada teh dan kopi. Konsumsi teh dan kopi cukup tinggi yaitu 4 gelas per orang per hari. Konsumsi kedua jenis minuman ini tinggi karena penduduk di Dusun Batur memiliki kebiasaan mengkonsumsi minuman tersebut sebagai minuman utama seharihari. Penduduk tidak terbiasa mengkonsumsi air putih sebagai minumannya.

Adanya budaya mengkonsumsi kopi dan teh manis yang tinggi serta data yang menunjukkan kecenderungan mengkonsumsi gula berlebih menyebabkan perlunya perhatian khusus terhadap asupan gula pada penduduk Dusun Batur, sebab konsumsi makanan/minuman manis secara berlebihan memiliki 4,2 kali lebih beresiko terkena obesitas dan 2 kali lipat beresiko terkena diabetes mellitus (Burhan et al., 2005; Wicaksono, 2011).

\section{Konsumsi Garam}

Pada tabel 4 disajikan rata - rata asupan garam menurut kelompok umur dan jenis kelamin. Secara keseluruhan, rata - rata total asupan garam sebesar 6.6 gram per orang per hari. Konsumsi garam pada penduduk perempuan lebih tinggi yaitu sebesar 6.8 gram per orang per hari dibandingkan dengan laki - laki yaitu 6.5 gram per orang per hari. Asupan garam tertinggi pada kelompok usia $56-65$ tahun yakni 7.2 gram per orang per hari dan terendah pada kelompok usia 40 -45 tahun yakni 6.3 gram per orang per hari. Ratarata konsumsi garam pada semua kelompok umur dan jenis kelamin sudah melebihi batas yang dicantumkan dalam Permenkes No. 30 tahun 2013, yakni $<5$ gram per hari.

Gambar 2 menunjukkan penyebaran data asupan garam berdasarkan kelompok umur pada responden laki-laki dan perempuan. Pada responden laki-laki (2a), pola penyebaran data di semua kelompok umur relatif sama, namun pada kelompok usia 56-65 tahun data tidak simetris, artinya tidak mengikuti distribusi normal. Pada gambar $2 b$ yaitu data responden perempuan, nampak bahwa pada kelompok usia 56-65 tahun penyebaran datanya terpusat sedangkan kelompok usia > 65 penyebaran data paling menyebar dan satu-satunya yang tidak mengikuti distribusi normal.

Garam merupan salah satu bumbu dapur yang digunakan untuk menambah cita rasa dalam makanan. Garam digunakan oleh tubuh untuk mengatur keseimbangan cairan namun demikian konsumsi garam berlebihan dapat menyebabkan timbulnya masalah kesehatan. Sejumlah penelitian menunjukkan adanya hubungan yang erat antara konsumsi garam berlebih dengan penyakit jantung, hipertensi, dan stroke (Andriaansz et al., 2016; Sylvanus dan Raya, 2014; Zuraida, 2015).

Dari analisis data diatas, rata - rata konsumsi garam melebihi batas rekomendasi dari pemerintah bahkan lebih tinggi dari rata - rata 
Tabel 4 | Rerata asupan garam (g/org/hr) menurut karakteristik kelompok umur dan jenis kelamin.

\begin{tabular}{lllllll}
\multirow{2}{*}{$\begin{array}{l}\text { Umur } \\
\text { Umompok }\end{array}$} & \multicolumn{2}{c}{ Laki - Laki } & \multicolumn{2}{c}{ Perempuan } & \multicolumn{2}{c}{ Total } \\
\cline { 2 - 6 } & Rerata \pm SD & Min-Max & Rerata \pm SD & Min-Max & Rerata \pm SD & Min-Max \\
\hline $\mathbf{4 0 - 4 5}$ thn & $6.2 \pm 1.1$ & $4.7-8.7$ & $6.3 \pm 1.2$ & $4.3-8.9$ & $6.3 \pm 1.1$ & $4.3-8.9$ \\
\hline $\mathbf{4 6 - 5 5}$ thn & $6.1 \pm 1.2$ & $3.5-8.7$ & $6.9 \pm 1.3$ & $4.3-9.5$ & $6.6 \pm 1.4$ & $3.5-9.5$ \\
$\mathbf{5 6 - 6 5}$ thn & $7.3 \pm 1.3$ & $4.8-10.4$ & $7.1 \pm 1.3$ & $4.3-10.4$ & $7.2 \pm 1.3$ & $4.3-10.4$ \\
\hline >65 thn & $6.3 \pm 1.6$ & $4.4-10.0$ & $6.8 \pm 1.4$ & $4.4-8.9$ & $6.6 \pm 1.4$ & $1.4-10.0$ \\
\hline Total & $6.5 \pm 1.3$ & $3.5-10.4$ & $6.8 \pm 1.3$ & $4.3-10.4$ & $6.6 \pm 1.3$ & $3.5-10.4$ \\
\hline
\end{tabular}

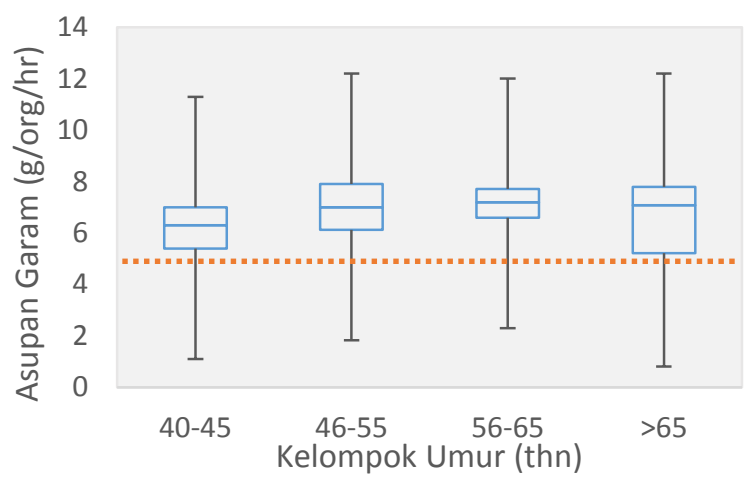

a

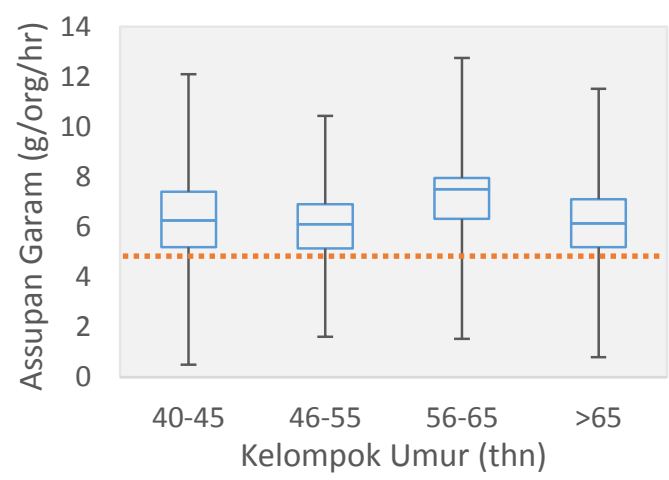

b

Gambar 2 | Konsumsi garam berdasarkan kelompok umur

a. Laki-laki. b. Perempuan. (garis merah putus-putus = batas atas rekomendasi Permenkes No. 30 Tahun 2013)

konsumsi penduduk Indonesia. Sebanyak $73.7 \%$ responden mengkonsumsi garam melebihi batas rekomendasi dari Permenkes No. 30 Tahun 2013 yang terbanyak pada kelompok usia $56-65$ tahun (Prihatini et al., 2016).

Tingginya konsumsi garam pada penduduk bukan hanya disebabkan penambahan garam pada makanan tetapi juga disebabkan karena kebiasaan menambahkan garam pada minuman teh atau kopi. Penambahan garam pada minuman teh atau pun kopi yang mereka konsumsi ini sudah menjadi kebiasaan yang mereka lakukan turun temurun. Penduduk Dusun Batur menyakini bahwa dengan mengkonsumsi teh atau kopi menggunakan garam selain menghemat biaya untuk membeli gula juga bisa meningkatkan stamina tubuh mereka. Hal ini karena larutan garam merupakan larutan elektrolit yang berfungsi untuk mengatur keseimbangan cairan dan menggantikan cairan tubuh yang hilang (Norman, 2011).
Tingginya konsumsi garam pada responden perlu mendapat perhatian khusus jika tidak, dikhawatirkan akan menambah lonjakan terjadinya peningkatan kasus penyakit kardiometabolik. Konsumsi garam yang tinggi diketahui meningkatkan resiko terjadinya hipertensi, stroke, dan serangan jantung (Permenkes, 2014). Kebiasaan konsumsi makanan asin memiliki resiko hipertensi lebih tinggi dibandingkan dengan orang yang tidak memiliki kebiasaan konsumsi makanan asin karena semakin rendah asupan garam, maka semakin rendah pula tekanan darah (He et al., 2012). Dari data Riskesdas tahun 2013 menunjukkan, 25.8 persen penduduk Indonesia menderita penyakit hipertensi (Kemenkes RI, 2013). Dari data yang didapatkan di Puskesmas Getasan tahun 2014, penyakit hipertensi menempati peringkat pertama yaitu sebanyak 119 kasus dalam kategori penyakit tidak menular di Desa Batur. 


\section{Konsumsi Lemak}

Lemak merupakan salah satu zat gizi yang diperlukan oleh tubuh, namun jika konsumsinya berlebihan maka dapat menimbulkan dampak buruk bagi kesehatan. WHO merekomendasikan konsumsi lemak tidak boleh lebih dari $30 \%$ dari kebutuhan energi (WHO, 2003). Di Indonesia berdasarkan Permenkes No. 30 Tahun 2013, merekomendasikan asupan lemak yaitu $<67$ gram per orang per hari.

Lemak yang dimaksudkan pada penelitian ini adalah lemak yang ditambahkan dalam bahan makanan seperti minyak dan lemak yang secara alami sudah terdapat pada bahan makanan misalnya daging dan santan. Hasil analisis rata-rata asupan lemak berdasarkan karakteristik kelompok umur dan jenis kelamin dapat dilihat pada Tabel. 5. Rata - rata asupan lemak total adalah 48,6 gram per orang per hari. Asupan lemak pada penduduk perempuan cenderung lebih tinggi yaitu sebesar
49.4 gram per orang per hari, dibandingkan dengan penduduk laki - laki yaitu $\mathbf{4 7 . 5}$ gram per orang per hari. Responden yang mengkonsumsi lemak tertinggi pada kelompok umur 56 - 65 tahun sebesar 50.9 gram per orang per hari dan terendah pada kelompok umur $40-45$ tahun yaitu 47.4 gram per orang per hari. Konsumsi lemak berdasarkan data pada tabel 5 tidak melebihi batas dari Permenkes No. 30 Tahun 2013 yang merekomendasikan bahwa asupan lemak <67 gram per orang per hari. Jika dibandingkan dengan data rata-rata konsumsi lemak penduduk Jawa Tengah yaitu 46,4 gram per orang per hari untuk usia 19 55 tahun dan 44,4 gram per orang per hari untuk usia $<55$ tahun, maka rata-rata konsumsi lemak pada tabel 5 lebih tinggi (Santoso et al., 2014).

Penyebaran data asupan lemak menurut kelompok umur laki-laki dan perempuan pada gambar 3 tidak berbeda secara signifikan, semua panjang bidang persegi berukuran hampir sama. Berdasarkan simetris tidaknya data maka dapat

Tabel 5 | Rerata asupan lemak (g/org/hr) menurut karakteristik kelompok umur dan jenis kelamin.

\begin{tabular}{lllllll}
\multirow{2}{*}{$\begin{array}{l}\text { Uelompok } \\
\text { Umur }\end{array}$} & \multicolumn{2}{c}{ Laki - Laki } & \multicolumn{2}{c}{ Perempuan } & \multicolumn{2}{c}{ Total } \\
\cline { 2 - 7 } & Rerata \pm SD & Min-Max & Rerata \pm SD & Min-Max & Rerata \pm SD & Min-Max \\
\hline $\mathbf{4 0 - 4 5}$ thn & $44.1 \pm 9.7$ & $24-65.5$ & $51.4 \pm 8.2$ & $38.5-63.7$ & $47.4 \pm 9.8$ & $24.0-65.5$ \\
$\mathbf{4 6 - 5 5}$ thn & $45.8 \pm 12.0$ & $25.3-73.1$ & $49.3 \pm 14.4$ & $25-78.6$ & $48.0 \pm 13.7$ & $25.0-78.6$ \\
\hline $\mathbf{5 6}$ - 65 thn & $52.6 \pm 12.5$ & $29.7-76.7$ & $49.4 \pm 10.9$ & $31.3-68.7$ & $50.9 \pm 11.7$ & $29.7-76.7$ \\
\hline >65 thn & $49.1 \pm 9.1$ & $29.4-61.3$ & $47.7 \pm 11.8$ & $24.9-66.0$ & $48.2 \pm 10.7$ & $24.9-66.0$ \\
\hline Total & $47.5 \pm 11.6$ & $24-76.7$ & $49.4 \pm 11.9$ & $24.9-78.6$ & $48.6 \pm 11.8$ & $24-78.6$
\end{tabular}

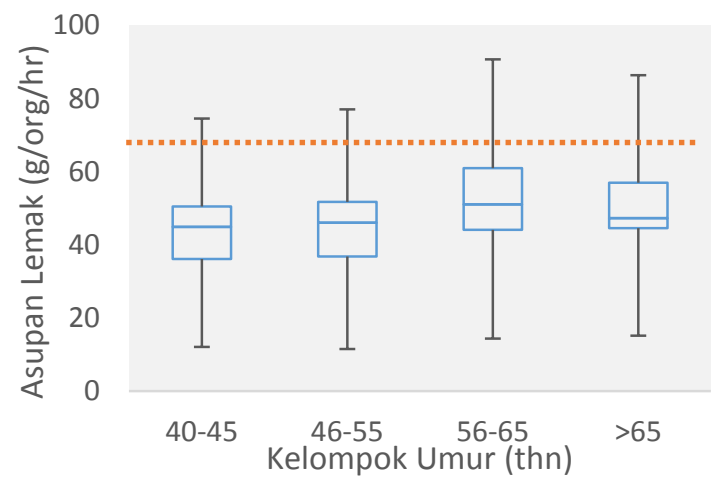

a

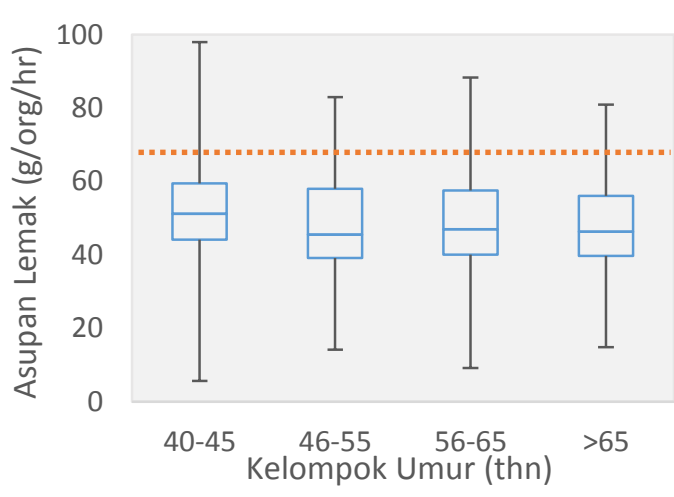

b

Gambar 3 | Konsumsi lemak berdasarkan kelompok umur

a. Laki-laki. b. Perempuan. (garis merah putus-putus = batas atas rekomendasi Permenkes No. 30 Tahun 2013) 
dilihat pada gambar 3a, semua garis median tidak membagi dua bidang sama besar artinya data tidak mengikuti distribusi normal, sedangkan pada gambar $3 b$, semua data mengikuti distribusi normal kecuali data untuk kelompok umur 46-55 tahun.

Lemak yang ada dalam bahan makanan berguna untuk tubuh sebagai sumber cadangan energi, media transportasi vitamin $A, D, E$, dan $K$, serta membantu menekan rasa lapar. Lemak memang dibutuhkan oleh tubuh, tetapi jika mengkonsumsi lemak secara berlebihan maka akan berbahaya bagi kesehatan jantung. Lemak yang ada didalam bahan makanan terutama yang berasal dari lemak hewani akan meningkatkan kolesterol darah. Kadar kolestrol yang tinggi berkaitan dengan peningkatan penyakit hipertensi (Almatsier, 2009).

Pemerintah melalui Peraturan Menteri Kesehatan nomor 30 tahun 2013 tentang pencantuman informasi kandungan gula, garam, dan lemak serta pesan kesehatan untuk pangan olahan dan pangan siap saji menyebutkan bahwa dalam mengkonsumsi lemak atau minyak tidak boleh lebih dari $67 \mathrm{~g}$ ( 5 sendok makan) per orang per hari, jika melebihi maka akan meningkatkan risiko hipertensi, stroke, dan serangan Jantung (Permenkes, 2014; He et al., 2012).

Berdasarkan wawancara yang dilakukan, sumber lemak utama responden adalah dari minyak kelapa sawit yang sering digunakan responden sebagai bahan untuk menggoreng makanan, santan, dan lemak yang sudah ada dalam bahan makanan responden seperti telur, dan daging ayam.

Dari analisis data diatas, rata - rata konsumsi lemak responden tidak melebihi batas rekomendasi Pemerintah dan tidak lebih tinggi dari rata - rata konsumsi penduduk Indonesia. Meski demikian sebanyak $7 \%$ responden mengkonsumsi lemak melebihi batas rekomendasi dari Permenkes No. 30 Tahun 2013, yang terbanyak pada kelompok usia 56 - 65 tahun. Konsumsi lemak responden yang tidak melebihi batas rekomendari dari Permenkes No. 30 Tahun 2013, disebabkan karena responden lebih menyukai makanan yang berbasis sayur - sayuran dan umbi - umbian dari hasil perkebunan mereka sendiri. Cara pengolahan makanan yang sering dilakukan adalah dengan cara direbus atau dikukus.

\section{Konsumsi Gula Garam dan Lemak}

Penduduk yang mengkonsumsi gula, garam, dan lemak melebihi batas rekomendasi dari Permenkes No. 30 Tahun 2013 akan memiliki resiko tinggi terkena penyakit metabolik. Pada tabel 6 . Dapat dilihat data persentase konsusmsi gula, garam, dan lemak berdasarkan karakteristik umur dan jenis kelamin. Sebanyak $21.5 \%$ responden mengkonsumsi gula diatas rekomendasi. Konsumsi gula tertinggi terjadi pada kelompok umur $40-45$ tahun yaitu sebesar 26\%. Menurut jenis kelaminnya, responden perempuan mengkonsumsi gula lebih tinggi (21.7\%) dibandingkan dengan laki - laki (19,3\%). Persentase responden yang mengkonsumsi garam di atas rekomendasi secara

Tabel 6 | Persentase asupan gula, garam, dan lemak menurut karakteristik kelompok umur dan jenis kelamin.

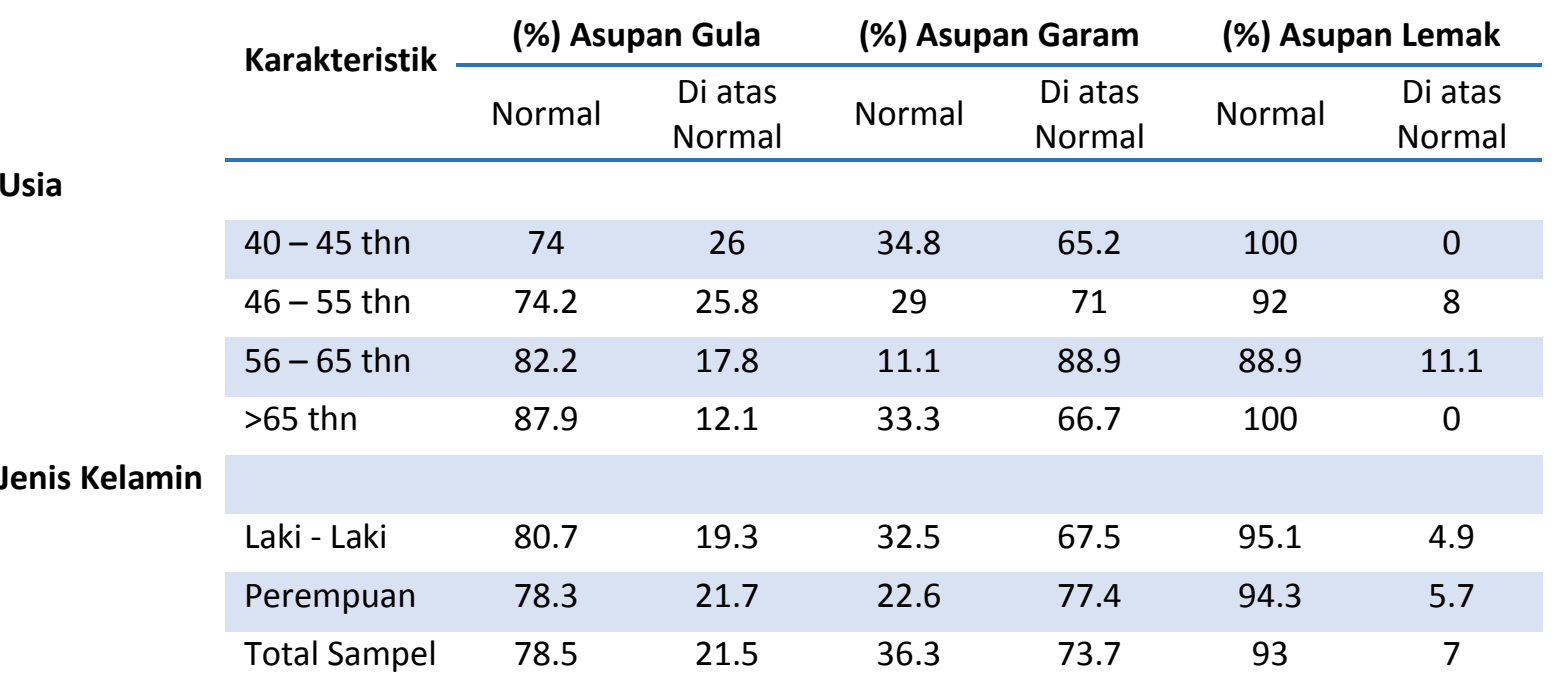


umum tinggi yaitu $73,7 \%$. Jika dilihat menurut kelompok umur persentase responden yang mengkonsumsi garam lebih dari rekomendasi dari Permenkes No. 30 Tahun 2013 lebih banyak dibandingkan persentase konsumsi garam yang sesuai rekomendasi. Konsumsi garam paling tinggi pada kelompok usia 56 - 65 tahun (88.9\%). Berdasarkan jenis kelamin konsumsi garam lebih tinggi pada perempuan (77.4\%) dibandingkan dengan laki - laki (67.5\%). Berbeda dengan konsumsi garam, persentase konsumsi lemak di atas normal secara total hanya $7 \%$, yang tertinggi pada kelompok usia 56 - 65 tahun. Pada kelompok perempuan sebesar $5.7 \%$ lebih tinggi dari laki - laki yaitu sebesar $4.9 \%$.

Jika dilihat dari asupan gula, garam dan lemak pada masing-masing kelompok maka penduduk pada kelompok umur 56 - 65 tahun memiliki persentase tertinggi dalam konsumsi garam dan lemak sedangkan untuk persentase konsumsi gula tertinggi pada kelompok umur $40-45$ tahun.

Konsumsi gula, garam dan lemak berlebih pada seseorang dapat meningkatkan resiko terkena penyakit tidak menular khususnya penyakit kardiometabolik seperti penyakit diabetes mellitus, hipertensi, jantung, dan stroke. Selain pola konsumsi, faktor resiko lain adalah obesitas dan usia sebab seseorang yang mengalami obesitas beresiko lebih tinggi untuk terkena penyakit kardiometabolik karena obesitas berhubungan dengan meningkatnya trigliserida (Saoegih dan Kukun, 2014; Rustika dan Oemiati, 2014). Seseorang yang berusia $\geq 45$ tahun memiliki peningkatan resiko terjadinya penyakit kardiometabolik karena menurunnya fungsi tubuh dalam proses metabolisme (Wicaksono, 2011).

Analisa data diatas menunjukkan persentase konsumsi garam (88.9\%) dan lemak (11.1\%) yang banyak terdapat pada kelompok umur lansia akhir (56- 65 tahun). Responden yang mengkonsumsi gula terbanyak terdapat pada kelompok umur dewasa akhir ( $40-45$ tahun) yaitu $26 \%$ yang dilihat dari data IMT pada usia ini memiliki kategori IMT gemuk terbanyak dibandingkan dengan kelompok umur lainnya. Keadaan ini perlu diwaspadai dari sekarang jika tidak akan meningkatkan resiko terjadinya penyakit kardiometabolik yang disebabkan karena penurunan sistem metabolisme akibat perubahan fisiologis (Ekpenyong et al., 2012; Wicaksono, 2011).

\section{Kesimpulan}

Konsumsi garam, dan gula sebagian besar responden tergolong tinggi sedangkan untuk konsumsi lemak responden mendekati batas rekomendasikan oleh Permenkes no 30 tahun 2013. Konsumsi garam dan lemak tertinggi pada kelompok umur 56 - 65 tahun sedangkan untuk konsumsi gula tertinggi pada kelompok umur 40 45 tahun. Hal ini perlu mendapatkan perhatian khusus karena konsumsi garam, gula yang berlebih dapat menyebabkan berbagai penyakit tidak menular seperti hipertensi dan diabetes mellitus tipe 2 yang prevalensinya di Indonesia semakin meningkat.

\section{Apresiasi}

Terimakasih kepada Dinas Kesehatan Kabupaten Semarang, Kecamatan Getasan, Kepala Desa Batur yang telah memberikan ijin untuk melakukan penelitian. Kepada Kepala Dusun Batur Kidul yang telah membantu dan memberikan ijin dalam pelaksanaan penelitian di lapangan dan para masyarakat Dusun Batur Kidul atas kesediaannya menjadi responden.

\section{Bibliografi}

1. Adriaansz, P. N., Rottie, J., dan Lolong, J. 2016 Hubungan Konsumsi Makanan dengan Kejadian Hipertensi pada Lansia di PUSKESMAS Ranomuut Kota Manado. Ejournal Keperawatan, 4(1), 2.

2. Almatsier, S. 2009. Prinsip Dasar IImu Gizi. Jakarta: PT Gramedia Pustaka Utama.

3. Badan Penelitian dan Pengembangan Kesehatan. 2014. Studi Diet Total : Survei Konsumsi Makanan Individu. Badan Penelitian dan Pengembangan kesehatan.

4. Balitbang Kemenkes RI. 2007. Riset Kesehatan Dasar; RISKESDAS. Jakarta: Balitbang Kemenkes RI.

5. Balitbang Kemenkes RI. 2013. Riset Kesehatan Dasar; RISKESDAS. Jakarta: Balitbang Kemenkes RI.

6. Bogers, R. P., Wanda, J. E. Bemelmans., Rudolf, T. Hoogenveen., Hendriek, C. Boshuizen., Mark, W., Paul, K., Rob, M. van Dam., Frank, B. Hu., Tommy, L. S. Visscher., Alessandro, M., Roland, J. Thorpe Jr., Konrad, J., Susanna, C., Bjørn, H. S., and Martin, J. 
Shipley. 2007. Association of overweight with increased risk of coronary heart disease partly independent of blood pressure and cholesterาol levels: a meta-analysis of 21 cohort stud 7 ies including more than 300,000 persons. Arch Intern Med. 167, $1720-8$.

7. Burhan, F. Z., Sirajuddin, S., dan Indriasari, R. 2005. Pegawai Pemerintahan Di Kantor Bupati Kabupaten Jeneponto. Jurnal MKMI, 1-14.

8. Departemen Kesehatan Republik Indonesia. 2009. Sistem Kesehatan Nasional. Jakarta

9. Dinkes Kabupaten Semarang. 2014. Profil Kesehatan Kabupaten Semarang. Dinas Kesehatan Kabupatan Semarang.

10. Ekpenyong, C.E., Udokang, N.E., Akpan, E.E., and Samson, T. 2012. Double Burden, NonCommunicable Diseases And Risk Factors Evaluation In Sub-Saharan Africa: The Nigerian Experience. European Journal of Sustainable Development, 249270.

11. Feng, L., Li, P., Wang, X., Hu, Z., Ma, Y., Tang, W., and Wang, F. 2014. Distribution and determinants of non communicable diseases among elderly uyghur ethnic group in Xinjiang, China. PLoS ONE. Journal.pone.

12. He, F. J., Campbell, N. R. C., and MacGregor, G. A. (2012). Reducing salt intake to prevent hypertension and cardiovascular disease. Revista Panamericana de Salud Pública, 32(4), 293-300.

13. Kemenkes. 2011. Penerapan Pola Konsumsi Makanan dan Aktivitas Fisik. Strategi Nasional Penerapan Pola Konsumsi Makanan dan Aktivitas Flsik. Jakarta: Kementrian Kesehatan RI.

14. Murti, Y. L., 2016. Hubungan Antara Kebiasaan Konsumsi Gula Dengan Kejadian Diabetes Mellitus Di Wilayah Kerja Puskesmas Leyangan Ungaran Timur Kabupaten Semarang. Naskah Publikasi.

15. Norman, H. 2011. Kandungan Natrium 2\% dan 5\% Dalam Minuman Isotonik Memperpendek Waktu Pemulihan. Tesis. Program Pascasarjana. Universitas Udayana. Denpasar.

16. Nugraha, A. 2014. Hubungan Indeks Massa Tubuh dengan Kadar Kolesterol Total pada Guru dan Karyawan SMA Muhammadiyah 1 dan 2 Surakarta. Universitas Muhammadiyah Surakarta.

17. Peraturan Menteri Kesehatan RI. 2014. Pedoman Gizi Seimbang. Menteri Kesehatan Republik indonesia.

18. Prasetyani, D., dan Sodikin. 2017. Analisis Faktor yang Mempengaruhi Kejadian Diabetes Mellitus (DM) tipe 2. Jurnal Kesehatan Al Irsyad (JKA). Vol X No 2.

19. Prihartini, S., Permaesih, D., dan Juliantri D. E. 2014 Asupan Natrium Penduduk Indonesia: Analisis Data
Survei Konsumsi Makanan Individu (SKMI). Gizi Indonesia.

20. Rawasiah, A. B., Wahiduddin, R., dan Rismayanti. 2012. Hubungan Faktor Konsumsi Makanan Dengan Kejadian Hipertensi Pada Lansia Di Puskesmas Pattingalloang. Naskah Publikasi.

21. Rustika, dan Oemiati, R. 2014. Penyakit Jantung Koroner (PJK) dengan obesitas di Kelurahan Kebon Kalapa, Bogor (Baseline Studi Kohor Faktor Risiko PTM). Buletin Penelitian Sistem Kesehatan, 17(4), 385-393

22. Santoso, B., Sulistiowati, E., Fajarwati, T., dan Pambudi, J. 2014. Studi Diet Total: Survei Konsumsi Makanan Individu Provinsi Jawa Tengah. Badan Penelitian Dan Pengembangan Kesehatan, 18-22.

23. Saoegih, R., dan Kunkun W. 2009. Obesitas Permasalahan dan Terapi Praktis. Jakarta : Sagung Seto.

24. Sylvanus, D., dan Raya, P. 2014. Pola makan dan hubungannya dengan kejadian stroke. Jurnal Gizi Dan Dietetik Indonesia, 2(2), 51-61.

25. WHO. 2003. Diet, nutrition and the prevention of chronic diseases. World Health Organization Technical Report Series, 916, i-viii-1-149.

26. Wicaksono, R. P. 2011. Faktor-Faktor yang Berhubungan dengan Kejadian Diabetes Melitus Tipe 2. Skripsi. Pendidikan Sarjana Kedokteran Fakultas Kedokteran, Universitas Diponegoro, Semarang.

27. Zuraida, R. 2015 . Faktor Risiko Pola Makan dan Hubungannya dengan Penyakit Jantung pada Pria dan Wanita Dewasa di Provinsi Lampung. Naskah Publikasi. 